DO SHARKS SWALLOW THEIR YOUNG FOR PROTECTION?

\section{To the Editor of Science:}

SIR: In the New York Tribune for July 7, 1880, under the heading "A Female Shark Captured," was printed a statement made to a reporter by Mr. Eugene G. Blackford, well and favorably known to the cummunity; not only as one of the largest dealers in fish at Fulton Market, but also as an enthusiastic co-operator with the United States Fish Commission. The essential parts of the statement are as follows: "A Porbeagle shark (Lamina punctata)* was caught off Great Neck, Long Island, and came into my possession not more than seven hours after death. From the immense size of her stomach I thought she must have swallowed a barrel or two of moss-bunkers, and to gratify my curiosity I opened her. I found ten little shark, evidently her offspring, and all just the same size-exactly two feet long. I should say they were about six months old, for a shark when hatched from the egg measures about four inches. It has been a disputed question anong tishermen whether young sharks in time of danger lo not seek safety in their mother's stomach. I think this case proves that they do, for the little ones ivere perfectly sound, with no mark of digestion upon them."

In answer to a request for more explicit information, Mr. Blacktcrl, August 25, wrote me a letter from which, with his permission, 1 extract the following: "Just as the men were about to open the shark I was called away. When 1 returned they showed me the ten young, but I dicl not preserve them. The men said they were in the stomach, but the viscera had been thrown away, so I could not verify their statement. As I understand it, sharks are oviparous and not viviparous, so they could not have been in the womo. Will you kindly let me have your opinion on this? Should another specimen ever come into my hands I shall take great care that it is scientifically examined if you think it is of importance."

In reply, I informed Mr. Blacklord that many species of sharks bring forth living young, and expressed the opinion that the little ones found by his men were really in the enlarged ovillucts rather than in the true stomach, and suggested that he should publish some qualification of the original account, or authorize me to do so for him.

As time passed without my hearing from him, I concluded that he was preparing a note upon the subject, and hoped, moreover, that no journal under scientific supervision would give eren a qualified sanction to the original statement without making enquiries like my own. Nevertheless, the paragraph in the Tribune was copied, substantially, into the Scientific American for July 3I, and formed the basis if the following " Zo logical Note" in the American Naturalist for October: "Mr. E. G. Blackfurd states that ten sharks, two feet in length and apparently about six months old, were tatien from the stomach o. a mackerel shark (Lamena punctuta), as if they had got there to avoid danger. Still, it is probable that sharks may eat their young."

Upon hearing of this dissemination of the etror. Mr. Blacklord wrote me on the 10 th and 28 th of thetober: "I wats under the impression that I wrote you belore to

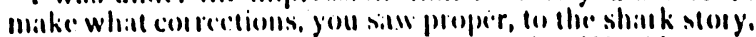

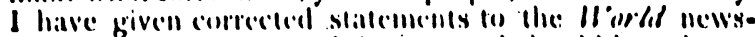
paper, and fo liorest and stecieme, and should he unly too happy to have you make further corrections, as there is nothing I regret so much as to have anything purporting to emannate Irom me that looks like a yarn."

Availing myselt of Mr. Blackford's permission I repeat, that, while it may not be right to deny the possibility of young sharks secking refuge from danger-as do some

* It is also known as the Mackerel shark, and ha been named Laynea * It is also known as the Mackerel snakes-by entering the mouth of the parent, the case in question furnishes not a particle of evidence in favor of that idea, and the little sharks were probably the unborn young, closely packed in the enlarged oviducts of the mother.

B. G. WILIER.

Corneli. University, Ithach, N. Y., Nov. $4,1880$.

\section{A FINE BOLIDE.}

BY EIWIN F. SAWYER.

A bolide, the most brilliant I have ever witnessed, appeared on the evening of October 25 th, at $8 \mathrm{~h}$. io min. C. M. T. It commenced near $\varepsilon$ Persei, at R. A. $55^{\circ}+40^{\circ}$ Dec., and exploded above a Aurigae (Capella), at R. A. $76^{\circ}+52^{\circ}$ Dec. When tirst observed it was as bright as a ist mag. star, and of a deep orange color. As it slowly proceeded it grew rapidly brighter, (its color in the meanwhile changing to light yellow and then white) first excecting if (Jupiter) in brilliancy, and then \& (Venus), and at the moment of the explos.on was many times brighter than the latter pianet. Seteral distinct flashes were noted during its flight. At the moment of explosion (accompanied by a very vivid tlash) the nucleus appeared somewhat elongated and of a pale green color, while the points of light and sparks radiating from it were of a beautiful red. During the first half of its course there appeared to be little or no sireak accompanying the bolide : but during the latter part of its path a broad and intensely white streak was olsserved, which, however, disappeared almost immediately alter the extinction of the nucleus.

The bolide was three and a half seconds in traversing a path of 17 , its velocity gradually increasing up to the point of explosion. No detonation was heard, although particularly listened for.

'The radiant point of this bolide was somewhere along its apparent path prolonged backwards. This path when carried back passes a few degrees north of $\varepsilon$ Arietis, and remarkably close to a radiant point of an important meteor shower, lately determined and particularly described by Mr. IV. F. Denning, F.R.A.S., in the Sicience ()bsiraier, Vol. I, No. 7. This shower appears to enclure from October 20 h 10 Novenber 13th, with a maximum on October 3I-Nov. 4th. The meteors trom this shower are generally slow moving and very bright. 'Two bodies, equal in brightness to Venus, were obseried in England on the evening of November th $^{\text {th }} 1877$, by Messrs. Wood and Backhouse, and traced to this radiant.

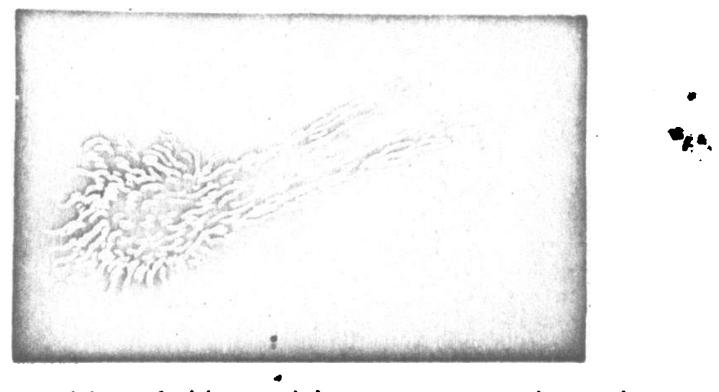

The position of this special meteor seream is at nhout K. $\Lambda .43^{\prime}+22^{\prime \prime}$ mear Arletis. Several quite bripht and short meteors (including one nearly stitionary) belonging to this shower were observed by the writer trom Novi. 7 to 19 th, 1879 , and giving a well determined position as at R. A, $47^{\circ}+24^{\circ}$. A rough sketch of the bolide as it appeared at the moment of explosion is here given.

Duplicate observations of this fine bolide are desired and would be of great value.

Cambridgepurt, Oct. 3rst, 1880. 